\title{
Temperature, recreational fishing and diapause egg connections: dispersal of spiny water fleas (Bythotrephes longimanus)
}

\author{
W. Charles Kerfoot · Foad Yousef • \\ Martin M. Hobmeier • Ryan P. Maki • \\ S. Taylor Jarnagin · James H. Churchill
}

Received: 6 July 2010/ Accepted: 4 February 2011/Published online: 4 September 2011

(C) The Author(s) 2011. This article is published with open access at Springerlink.com

\begin{abstract}
The spiny water flea (Bythotrephes longimanus) is spreading from Great Lakes coastal waters into northern inland lakes within a northern temperature-defined latitudinal band. Colonization of Great Lakes coastal embayments is assisted by winds and seiche surges, yet rapid inland expansion across the northern states comes through an overland process. The lack of invasions at Isle Royale National Park contrasts with rapid expansion on the nearby Keweenaw Peninsula. Both regions have comparable geology, lake density, and fauna, but differ in recreational fishing boat access, visitation, and containment measures. Tail spines protect Bythotrephes against young of the year, but not larger fish, yet the unusual thick-shelled diapausing eggs can pass through fish
\end{abstract}

W. C. Kerfoot $(\bowtie) \cdot$ F. Yousef · M. M. Hobmeier Department of Biological Sciences and Lake Superior Ecosystem Research Center, Michigan Technological University, Houghton, MI 49931, USA

e-mail: wkerfoot@mtu.edu

\section{R. P. Maki}

Voyageurs National Park, 415 S Pokegama Avenue, Grand Rapids, MN 55744, USA

\section{S. T. Jarnagin}

Department of Biological Sciences and Lake Superior Ecosystem Research Center, Michigan Technological University, Houghton, MI 49931, USA

J. H. Churchill

Department of Physical Oceanography, Woods Hole Oceanographic Institution, Woods Hole, MA 02543, USA guts in viable condition. Sediment traps illustrate how fish spread diapausing eggs across lakes in fecal pellets. Trillions of diapausing eggs are produced per year in Lake Michigan and billions per year in Lake Michigamme, a large inland lake. Dispersal by recreational fishing is linked to use of baitfish, diapausing eggs defecated into live wells and bait buckets, and Bythothephes snagged on fishing line, anchor ropes, and minnow seines. Relatively simple measures, such as on-site rinsing of live wells, restricting transfer of certain baitfish species, or holding baitfish for $24 \mathrm{~h}$ (defecation period), should greatly reduce dispersal.

Keywords Spiny cladoceran - Dispersal . Temperature $\cdot$ Diapausing eggs $\cdot$ YOY fish

\section{Introduction}

Biological invasions of the Laurentian Great Lakes began during European settlement and accelerated with the spread of shipping, commerce, waterway connections, and highways. Ricciardi (2006) estimated that at least 182 new organisms were introduced into the Great Lakes since the early 1800s, whereas Mills et al. (1993) suggested that at least $10 \%$ had measurable impacts on the ecosystem. If the introductions reduce "biological integrity", some have predicted an "invasion meltdown" scenario in 
which interactions between introduced species facilitate the establishment of new invaders (Ricciardi 2001). Effects of species like the sea lamprey (Petromyzon marinus) and zebra mussels (Dreissena polymorpha) are well known, but less conspicuous taxa like invasive zooplankton are now receiving attention, as the Great Lakes act as a source for colonization of inland lakes (Bollens et al. 2002).

In the first phase of New World geographic expansion, the spiny water flea (Bythotrephes longimanus) invaded all of the Great Lakes between 1984 and 1988 (Cullis and Johnson 1988; Sandgren and Lehman 1990). This species is characterized by a relatively large size and long, barbed caudal appendage (Fig. 1a). Several studies subsequently clarified population dynamics and food-web interactions within the Great Lakes. Early on, the long tail spine was demonstrated to protect Bythotrephes from small young of the year (YOY) fish (Barnhisel 1991a, b; Barnhisel and Harvey 1995), although bigger fish could ingest large numbers of adults (Keilty 1988; Mills et al. 1992; Branstrator and Lehman 1996). The spiny water flea was shown to be epilimnetic with mid-summer density oscillations (Berg and Garton 1988; Lehman 1991; Lehman and Cáceres 1993), to have high energetic demands (Lehman and Cáceres 1993; Yurista et al. 2010), and to depress herbivorous cladocerans such as Daphnia mendotae, D. retrocur$v a$, and Bosmina (Lehman and Cáceres 1993; Schulz and Yurista 1999; Barbiero and Tuchman 2004). Bythotrephes' diets were examined from stomach contents (Lehman and Branstrator 1995; Schulz and Yurista 1995), and diapausing eggs were quantified and hatched (Yurista 1997). A few investigations clarified which fish prey on Bythotrephes (Baker et al. 1992; Bur and Klarer 1991) and looked at potential indirect food-web effects between fish and Bythotrephes (Barnhisel and Kerfoot 1994; Schulz and Yurista 1999).

After colonizing embayments through coastal water connections, Bythotrephes began to invade inland lakes (MacIsaac et al. 2000, 2004). Much of the available inland small lake information comes from Harp Lake, Ontario (Yan and Pawson 1997) and Lake Michigamme, Upper Peninsula of Michigan (Jarnagin 1998; Jarnagin et al. 2000, 2004). In both lakes during the daytime, workers postulated that egg-carrying adult Bythotrephes sought shelter in epilimnetic strata between the bottom of the photic zone and the top of
Fig. 1 a Map shows the geographic distribution of the spiny cladoceran (Bythotrephes, insert), based on recent surveys. Red dots signify presence of Bythotrephes, whereas blue dots record absence (large red and pale blue, from 83 lake survey). The spiny cladoceran is present in all the Great Lakes, although Lake Erie populations show severe oscillations. Bythotrephes southern distribution appears sensitive to ambient air and associated lake epilimnetic temperatures, explaining the lack of inland records across southern Minnesota, Wisconsin, and Michigan. Exceptions are large, deep lakes with cooler epilimnion temperatures, such as the Great Lakes. b Example of lake surface temperatures derived from Landsat 5 (band 6, temperature) imagery, lower Peninsula of Michigan, plotted against $\log _{10}$ lake size (hectares). Values are plotted for over 650 lakes on August 29, 2010. Maximum air temperature was $26^{\circ} \mathrm{C}$. Note the large number of lakes with surface temperatures at Bythotrephes, physiological stress values of $24-26^{\circ} \mathrm{C}$ (for linear regression details, see inset)

the hypolimnion. In Harp Lake, Bythotrephes caused shifts in zooplankton size and species composition, as they favored large-bodied cladocerans while reducing small cladoceran abundance and overall species richness (Yan et al. 2001, 2002). These findings were similar to mesocosm investigations from a Swedish lake, within Bythotrephes' natural habitat (Wahlstrom and Westman 1999). In Long Lake, Michigan, researchers found that spiny cladocerans consumed 1.5-5 times the zooplankton biomass consumed by yellow perch, underscoring the important energetic role of Bythotrephes in inland lake food webs (Hoffman et al. 2001). Bythotrephes could also affect native fish by forming spine boluses in stomach or intestines (lake herring, Coulas et al. 1998) or by puncturing the stomachs of small baitfish (Compton and Kerfoot 2004).

Many inland lakes appear to possess habitat suitable for Bythotrephes colonization and thus remain vulnerable to invasion (MacIsaac et al. 2000; Yan et al. 2002). Early geographic surveys of Bythotrephes documented inland expansion (Yan et al. 1992; Jarnagin 1998; Branstrator et al. 2006), but until recently the exact nature of the northern geographic pattern was unclear. Here we report geographic sampling that helps clarify the relationship to temperature, and discuss two dispersal mechanisms (wind-induced channel surges and recreational boating). The first dispersal mechanism incorporates a simple coastal pumping feature, related to wind direction and magnitude, that aids colonization of embayments. The second mechanism, recreational boating transfer, incorporates viable passage of Bythotrephes' diapausing eggs through fish's 
(a)
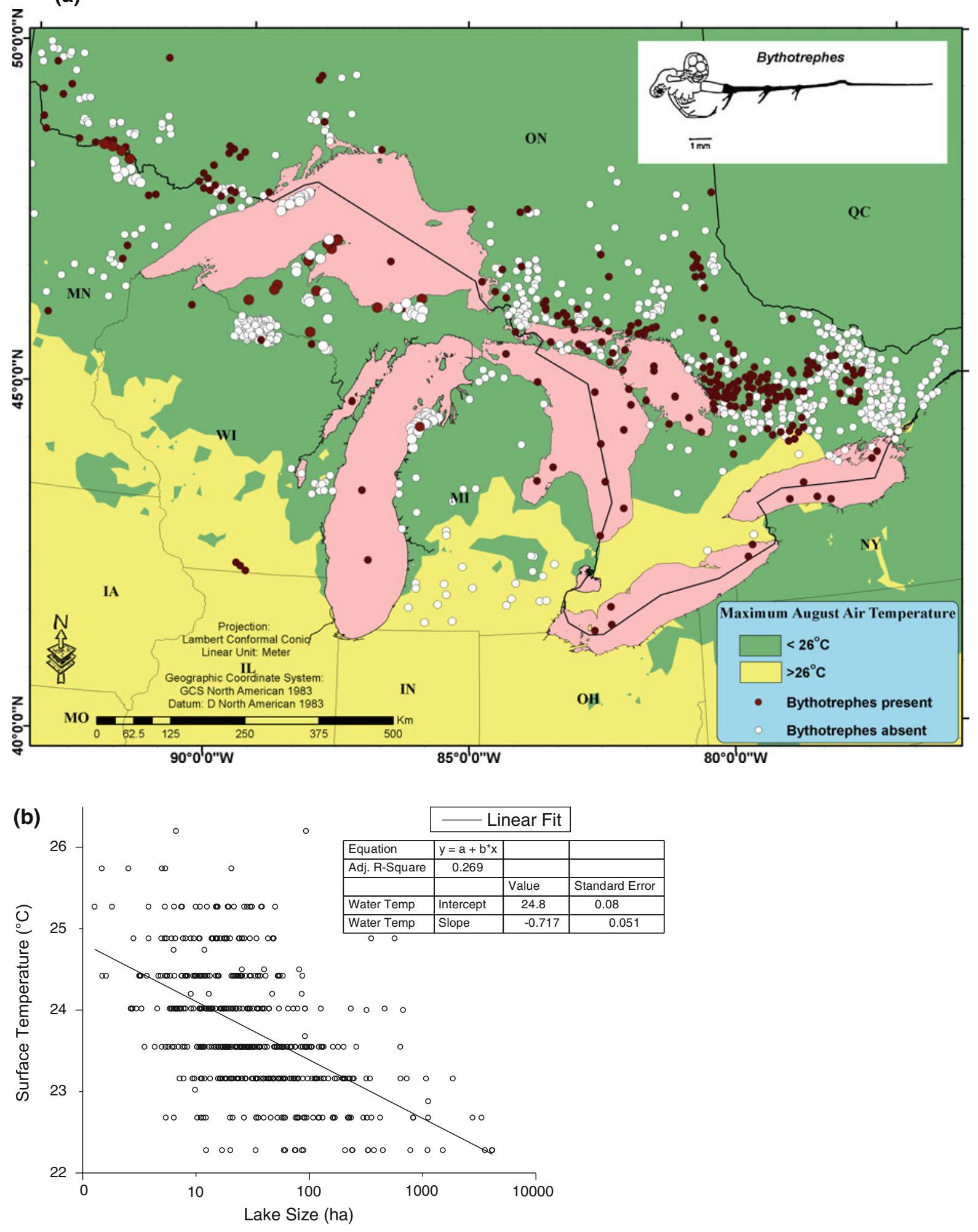
guts (Jarnagin et al. 2000; Kerfoot et al. 2000, 2009). Although very fish size-specific, enormous numbers of Bythotrephes' diapausing eggs seem ingested by fish each year and spread around lakes. Yet poor boat practices and use of baitfish opens potential dispersal between lakes. We argue that recreational fishing activity is the primary vector of inland geographic spread, through: (1) the use of live wells and bait fish (Jarnagin et al. 2000; Compton and Kerfoot 2004) and (2) the transfer of Bythotrephes snagged onto fishing lines, anchor ropes, nets, or seines. If the primary vector is recreational fishing, we emphasize that spread can be reduced through a series of relatively simple protective measures.

\section{Methods and materials}

Geographic survey: Bythotrephes presence in inland lakes and correlations with temperature and recreational boat use factors

When sieved from sediments, spines and diapausing eggs of Bythotrephes are easy to distinguish and count (Hall and Yan 1997; Jarnagin et al. 2004). An Ekman sample can provide information on local abundance and establishment of an egg bank, an important factor in long-term within-lake recruitment and persistence. Thus sieving of sediment provides a simple way of determining if Bythotrephes has been present in a lake's history, although the method does not distinguish whether populations are currently active. Using this approach, we surveyed 83 northern Michigan and Minnesota lakes during the summers of 2008-2010, concentrating in and around National Park lands (Sleeping Bear Dunes National Lakeshore, Pictured Rocks National Lakeshore, Isle Royale National Park, Voyageurs National Park), the Upper Peninsula of Michigan, and intervening inland stretches (Fig. 1a). Sampling was done from a canoe or small boat. Bottom sediments were collected with a standard $7 \mathrm{~kg}$ Ekman grab sampler $(15 \times 15 \times$ $15 \mathrm{~cm} ; 232 \mathrm{~cm}^{2}$ ), and released into a 20-1 bucket with a $350 \mu \mathrm{m}$ Nitex netting bottom. Fine sediments passed through, returning to the lake. The sieved fraction was then washed into a plastic collection bottle, preserved with $10 \%$ sugar/formalin, and stored in a Hobart $4{ }^{\circ} \mathrm{C}$ walk-in incubator until counted. Extreme measures were taken (formalin preservation of sediment samples, boiling water immersion of sampling gear, washing down canoes) to insure that Bythotrephes was not spread from lake to lake during surveys. Our survey results were added to a map prepared by John Zoltak for the Ontario Federation of Anglers and Hunters (2010), with additional records from Branstrator et al. (2006), Alexander and Hotchkiss (2009), EPA's National Lakes Assessment (2010), USGS (2010), and Weisz and Yan (2010).

Temperature studies have been conducted for Midwest lakes, but most are in the context of global warming (Meisner et al. 1987; Magnuson et al. 1990; Hondzo and Stefan 1993). Model studies incorporate weather parameters like solar radiation, air temperature, dew point temperature, wind speed, wind direction, and precipitation. Usual lake properties include morphometry (area-depth-volume) and Secchi depth (turbidity, productivity). However, we were interested in relatively simple relationships between ambient air temperature, lake size and epilimnetic temperature, ones that could be measured during midsummer high temperature periods.

Given the recent public release of Landsat 5 imagery, lake temperatures could be directly measured over a wide range of lake sizes. August regressions showed that epilimnetic temperatures for small lakes usually followed ambient air temperatures, whereas two orders of magnitude larger (and deeper) lakes would have slightly cooler temperatures, $1.5-2.0^{\circ} \mathrm{C}$ less. We provide an example (Fig. 1b) by plotting surface temperatures for over 650 randomly selected lakes from the Lower Peninsula of Michigan. In this example, Landsat 5 band 6 temperatures come from a cloud-free set of images on 29 August 2010. The software program ENVI was used to mosaic and subset the lakes. We used ERDAS IMAGIN to average surface temperatures for each lake, and ARCGIS to insert temperatures into corresponding polygons. Additional information on colonized lakes came from Northern and Southern Peninsula of Michigan surveys (All-outdoors Atlas and Field Guides 2008; Upper Peninsula Michigan Fishing Map Guides). These provided information on lake maximum depths, proximity to major highways, and recreational boat access.

Colonization of embayments by water exchange and effects of high summer temperatures

Using Portage Lake as an example, we discuss how water flow associated with wind speed and direction 
creates opportunities for spiny cladocerans to invade coastal embayments. To underscore subsequent sensitivity of populations to ambient temperatures, we characterized the occupied lake site relative to maximum summer temperature. Local deployment of temperature probes allowed documentation of yearly temperature fluctuations. Bythotrephes colonized Portage Lake during a relatively cool summer (1993), and persisted until two consecutive warm summers, 1998-1999 (Compton and Kerfoot 2004). Since 1999, the species has not successfully recolonized Portage Lake.

The temperature data used in the Keweenaw Waterway study came from model Stow Away-IS probes (Onset Computer Corporation) deployed at North and South Entries, in addition to ones set in Portage Lake. Wind data came from NOAA buoy 45006, located $95 \mathrm{~km}$ west of the North Entry, and the Stannard Rock C-MAN station, located $95 \mathrm{~km}$ to the east-northeast of the Waterway's South Entry. Wind speed and direction variables from the two NOAA wind-monitoring stations were correlated at $R^{2}=0.89$. To facilitate visual interpretation, all North and South Entry wind and temperature series shown here were filtered with a 33-h half-power point filter. This procedure attenuated fluctuations with periods of a day or less, but left lower frequency fluctuations largely intact. These lower frequency fluctuations comprised the majority of the temperature signal. Typically, filtering reduced the overall variance of a temperature series by less than $10 \%$.

The temperature probes at North Entry were set on an exposed piling at the North Entry U.S. Coast Guard station, whereas South Entry probes were set on Buoy \#1, near the end of the South Entry breakwater. Additional probes were set at three locations in Portage Lake: a navigation buoy at Michigan Technological University (MTU), a fixed buoy at Pilgrim Point (PLG), and a navigation buoy in the central portion of the lake (R28). The data at MTU and PLG were from probes at 1-m depth (epilimnion), whereas the data from R28 were from a probe at 9-m depth (hypolimnion). The probes were set to record temperatures over a -5 to $32^{\circ} \mathrm{C}$ range with a $0.1^{\circ} \mathrm{C}$ resolution, and an accuracy rating of $\pm 0.4^{\circ} \mathrm{C}$ at $21^{\circ} \mathrm{C}$. Measurement intervals ranged between 24 and $60 \mathrm{~min}$. Detailed heat flux calculations, and discussion of pertinent meteorological variables for Portage Lake overturns, can be found in Churchill and Kerfoot (2007).
Transfer of diapausing eggs by fish: ingestion of eggs and sediment trap studies of spine/egg deposition in lakes Michigan and Michigamme

Young of the year fish were seined from nearshore beach environments of Michigamme Lake and Voyageurs National Park. Sizable subsamples (60-250 fish) of yellow perch (Perca flavescens, ranged $35-140 \mathrm{~mm}$ in total length, TL) were dissected, with stomach and intestine contents examined. We took samples in mid- to late-summer, when Bythothrephes were carrying diapausing eggs. Critical measurements on fish included: fish standard length, and number of Bythotrephes (spine counts) and diapausing eggs in stomachs. Fish scale aging was done to separate large YOY from year-1 cohorts.

Use of sediment traps in colonized lakes, in conjunction with fish surveys and gut analyses, can also indicate the importance of fish predation, i.e. how many spines are broken ("fish gut passage") before they hit the sediment-water interface. Gut passage causes characteristic injuries to spines (loss of lateral barbs, fragmentation of the central spine; Jarnagin et al. 2004).

Studies from Lakes Michigan, Michigamme, and Voyageurs National Park show that Bythotrephes do not overwinter as free-swimming stages, but rely on over-wintering diapausing eggs (Yurista 1997; Jarnagin 1998; Jarnagin et al. 2004). By using sediment traps, we also attempted to estimate diapausing egg production in a source Great Lake (Lake Michigan) and in a large inland lake (Lake Michigamme). To look at spine (mortality) and diapausing egg deposition patterns, we deployed standard and sequential sediment traps (Fig. 2) in several lakes. Standard cylindrical PVC traps were suspended in Lake Michigamme (1995-1997) and several lakes in Voyageurs National Park (Rainy, Namakan, Kabetogama; 2009). Sequential traps were placed at several deep and coastal sites in Lake Michigan between 1998 and 2001. The exceptional deployment in Lake Michigan during the NSF/ NOAA EEGLE (Episodic Events Great Lake Experiment) project gave us an opportunity to estimate yearly diapausing egg deposition. In the 1998-2002 Lake Michigan EEGLE project, the sampling of Bythotrephes densities was handled separately from sediment trap studies (Pothoven et al. 2001, 2003). Sediment trap deployment totals during the EEGLE project were 1997-1998 (10 traps at 7 locations), 
1998-1999 (17 traps at 11 locations) and 1999-2000 (13 traps at 9 locations). In Lake Michigan, traps in deep-water locations (T12, T27, T28) remained at the same location for three seasons, whereas shallowwater traps were switched between sites over the 3-year interval.

Details of the Great Lakes Environmental Research Laboratory (GLERL) sequential sediment trap design and calibration are discussed in Muzzi and Eadie (2002). The trap design was field tested prior to 1997 (Eadie 1997; Muzzi and Eadie 2002). The configuration (Fig. 2) was cylindrical with an aspect ratio (height:width) of 8:1. Constructed from a 160-cm length of standard 8-in diameter PVC pipe with an interior diameter of ca. $20 \mathrm{~cm}$ (collection area $=318 \mathrm{~cm}^{2}$ ). A 20-cm diameter funnel (Nalgene), with $45^{\circ}$ sloped sides and a relatively large diameter stem, was located at the bottom of the pipe. The top lip of the funnel was beveled to produce a continuous, sloping surface.

In the sequential sediment trap, a computercontrolled carousel contained twenty-three 60-ml (Nalgene) polyethylene sample bottles that rotated under the funnel at preprogrammed intervals. An upper, circular PVC roof-plate shielded bottles until time for exposure to the funnel. Each bottle used a nylon insert with an o-ring to seal against sediment seepage. The collection bottles were poisoned with $6 \mathrm{ml}$ of chloroform and filled with distilled water immediately prior to deployment. Sampling frequency was set at $8-14$ days during critical fall seasons and 30 days for stratified spring and summer seasons. Although a battery pack potentially allowed up to 2 year of operation, in the EEGLE project we retrieved traps after 4-6 months of operation.

Traps were deployed at various sites in Lake Michigan (Fig. 3) as anchored arrays using subsurface buoyed $0.93-\mathrm{cm}$ steel cable. In deeper waters, bottom traps were anchored $5 \mathrm{~m}$ above sediments, whereas top traps were tethered $30 \mathrm{~m}$ below the water surface. Arrays were deployed with groundlines of 180-360 m between two anchors. Retrieval was accomplished by snagging the groundlines with brass grapples, then hauling up the arrays. An acoustic release often served as a backup, if grappling was unsuccessful. During the project, retrieval of traps was nearly $100 \%$, although data were lost from several traps during 1998-1999 due to battery failure and from several coastal sites due to sediment and biotic (zebra mussel) plugging of funnel openings.

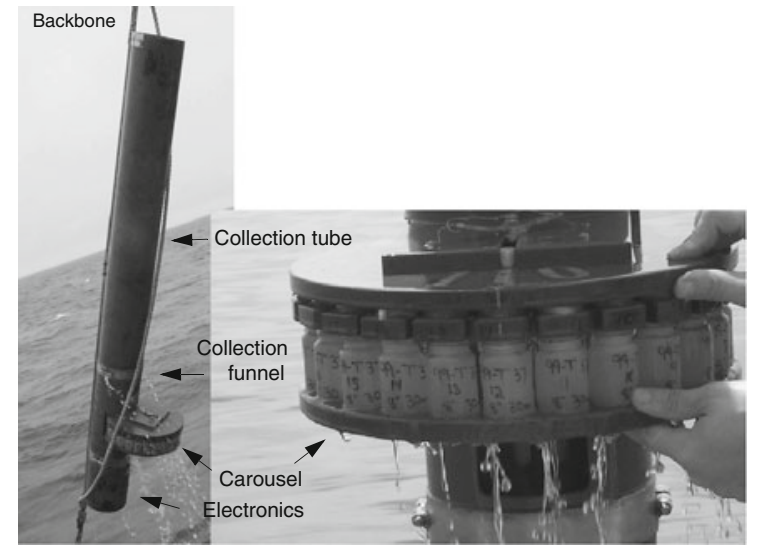

Fig. 2 Snapshot of the NOAA GLERL sequential sediment trap used in Lakes Michigan and Erie, illustrating essential components. Close-up of the carousel shows the labeled 60-ml Nalgene collection bottles that rotated under the collection funnel at computer-set time intervals

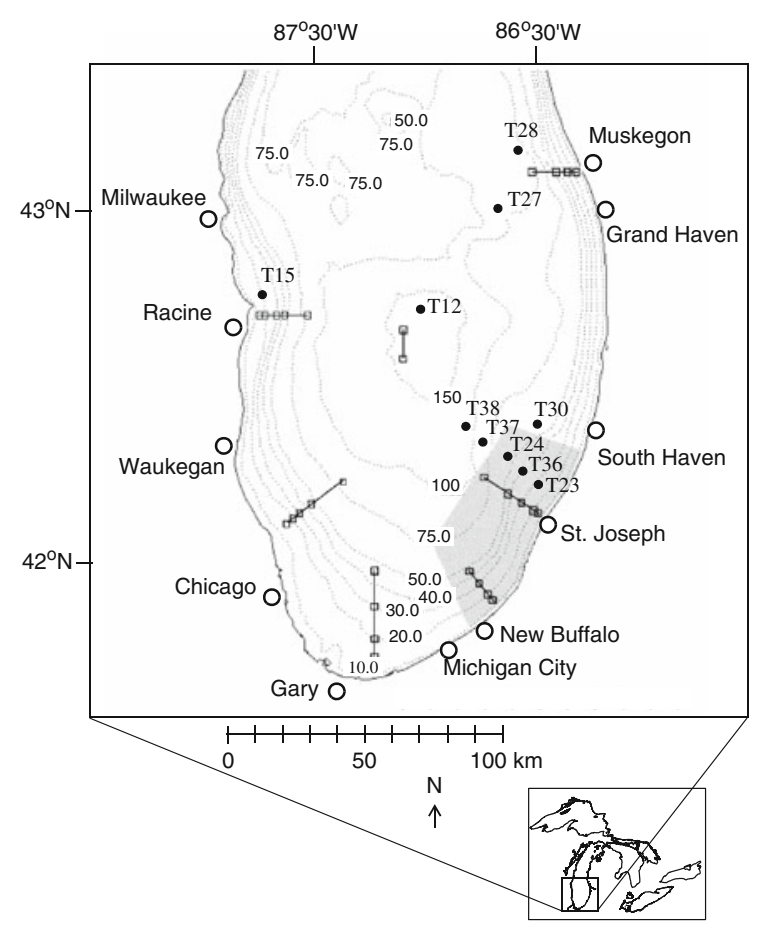

Fig. 3 Location of sequential sediment traps (black dots) and coastal and central transect stations (connected hollow squares) in Lake Michigan. Transect sites indicate positions of zooplankton samples used for Bythotrephes abundance estimates during the NSF/NOAA EEGLE project. Coastal transects are named for the closest large city (e.g. St. Joseph, Muskegon). Sites of sequential sediment traps are numbered

Lake Michigamme $\left(46.5^{\circ} \mathrm{N}, 88.1^{\circ} \mathrm{W}\right.$, altitude $474 \mathrm{~m}$ ), Upper Peninsula, Michigan, is a $17.6-\mathrm{km}^{2}$ multibasin lake with a maximum depth of $22 \mathrm{~m}$, and 
is darkly stained by tannic acids. Typical midsummer Sechi disk depths range from 1.5 to $2.7 \mathrm{~m}$, above a summer thermocline depth of $7-11 \mathrm{~m}$, creating a relatively cool $\left(14-20^{\circ} \mathrm{C}\right)$ epilimnetic zone in which adult Bythotrephes can hide from large fish (Jarnagin 1998; Jarnagin et al. 2004). Upper summer epilimnetic temperatures reached as high as $23-26^{\circ} \mathrm{C}$. In 1995 and 1996, the mean summer abundances of Bythotrephes were $67.4 \pm 29.1 / \mathrm{m}^{2}$ and $83.1 \pm 36.5 / \mathrm{m}^{2}$, respectively. Standard 8 " PVC sediment traps (aspect ratio, height:diameter, of 6) were suspended in combinations of three traps within wire baskets suspended by a nylon line between a float and anchor. The traps were tethered $1 \mathrm{~m}$ above the lake bottom. In the field, monthly collections were emptied into Nalgene bottles and preserved in $10 \%$ sugar/formalin.

After arrival at the lab, sediment samples were allowed to settle in a $4^{\circ} \mathrm{C}$ controlled temperature incubator for a day. The overlying water was siphoned off and the sample sieved through $350-\mu \mathrm{m}$ Nitex netting to remove spines and diapausing eggs. Both were filtered onto small $(45 \mathrm{~mm})$ Whatman filter pads, placed in small $(60 \times 15 \mathrm{~mm})$ Petri dishes, and kept at low temperature $\left(4-6^{\circ} \mathrm{C}\right)$ and dark conditions (no illumination) until laboratory identification and enumeration.

\section{Results}

Geographic survey: expansion along latitudinal temperature band

Out of 83 surveyed lakes, we found Bythotrephes in 23 (28\% of sampled lakes, Table 1). Colonized lake sizes ranged between 0.5 and $858 \mathrm{~km}^{2}$ (mean = $58 \mathrm{~km}^{2}, \quad \mathrm{SD}=177 \mathrm{~km}^{2}$ ), heavily influenced by Voyageurs' large lakes, whereas lake maximum depth ranged between 7.6 and $56.1 \mathrm{~m}$ (mean = $22.7 \mathrm{~m}, \mathrm{SD}=14.7 \mathrm{~m}$ ). When plotted with previous survey results (Boudreau and Yan 2004; Branstrator et al. 2006; Weisz and Yan 2010), Bythotrephes appears to be actively spreading within a northern latitudinal band that stretches from Ontario to Minnesota (Fig. 1a). Large colonized lakes in the northern tier conformed most closely to seasonal July-August epilimnetic lake temperatures of $18-26^{\circ} \mathrm{C}$. The pattern seems temperature-dependent, as the colonization band is situated north of the $27-30^{\circ} \mathrm{C}$ maximum surface air temperature isocline. Very few Bythotrephes populations were found in the Lower Peninsula of Michigan, southern Minnesota, and southern Wisconsin (exception Lake Mendota, Madison).

In terms of surface temperatures, lake size-surface temperature regression studies with August Landsat 5 images indicated that epilimetic temperatures in small lakes (1-10 ha) tended to track air temperatures, whereas lakes with larger areas (and depths) had slightly cooler temperatures $(Y=24.8-0.737 X$, where $Y$ surface temperature in ${ }^{\circ} \mathrm{C} ; X$ lake size in ha, $\log _{10}$ transformed; $1 \mathrm{SE}$ of intercept $=0.09^{\circ} \mathrm{C}$, of slope $=0.056^{\circ} \mathrm{C}$ ). Given the observed size distribution of lakes, about $95 \%$ of lakes in Michigan, Wisconsin, and Minnesota had epilimnetic temperatures that fell within $2-3^{\circ} \mathrm{C}$ of ambient July-August temperature highs. Landsat images showed that southern Michigan, Minnesota, and Wisconsin lakes had a high chance of experiencing epilimnetic temperatures between 24 and $30^{\circ} \mathrm{C}$ sometime during mid- to late summer, matching model results from Hondzo and Stefan (1993).

However, Bythotrephes in some very large lakes could escape temperature stress levels. For example, lakes with 2 orders of magnitude larger surface area (1,000 ha vs. 10 ha) tended to have epilimetic temperatures $1.4-2.0^{\circ} \mathrm{C}$ lower (Fig. 1a). However, these lakes were much less abundant. Extending the fit regression towards the sizes of the Great Lakes produced obvious exceptions, where surface temperatures could be much lower $\left(5-10^{\circ} \mathrm{C}\right.$ lower; i.e. $20^{\circ} \mathrm{C}$ when inland lakes were $30^{\circ} \mathrm{C}$ ). That is, Bythotrephes could tolerate temperatures in the southern Great Lakes, but could not spread inland because small, warm lakes would reach $26-30^{\circ} \mathrm{C}$ epilimnetic temperatures in mid- to late summer.

Colonization of embayments by water exchange and effects of high summer temperatures

May-July remote sensing sequences are excellent for examination of wind-influenced water exchange in Lake Superior embayments, because temperatures of inland and coastal waters are different. For example, The July 5, 2009, Landsat 5 scene in Fig. 4 shows the consequences of a southeastern wind moving across the Keweenaw Peninsula. The southeastern wind 
Table 1 Characteristics of Bythotrephes lakes, survey of Michigan Upper Peninsula, northern Minnesota, and National Parks, 2008-2010 (+ index for visitation, ranges from no boats
+ to ++++ numerous boats; index for bait fish use ranges from + very low, no observed bait buckets or fisherman use, to +++ , numerous bait buckets and bait fish use)

\begin{tabular}{|c|c|c|c|c|c|c|}
\hline Lake & $\begin{array}{l}\text { Area } \\
\left(\mathrm{km}^{2}\right)\end{array}$ & $\begin{array}{l}\text { Depth } \\
\text { (m) }\end{array}$ & $\begin{array}{l}\text { Hydrologic } \\
\text { connection }\end{array}$ & Public boat ramp & Visitation & $\begin{array}{l}\text { Bait fish } \\
\text { use }\end{array}$ \\
\hline Beaver Lake, MI & 3.2 & 11.9 & Downstream connection & 1 Boat ramp & + & + \\
\hline Crane Lake, MN & 12.5 & 24.3 & 5-Lake interconnection & Multiple & +++ & + \\
\hline Crystal Lake, MI & 39.2 & 53.3 & Inland & 3 Boat ramps & +++ & +++ \\
\hline Deer Lake, Alger Co., MI & 1.1 & 21.9 & $\begin{array}{l}\text { Lake Superior coastal, } \\
\text { downstream }\end{array}$ & 1 Boat ramp & ++ & ++ \\
\hline Gerald Lake, MI & 1.4 & 12.2 & Isolated inland & 1 Thru Roland & +++ & ++ \\
\hline Grand Sable Lake, MI & 2.7 & 25.9 & $\begin{array}{l}\text { Lake Superior coastal, } \\
\text { falls barrier }\end{array}$ & 1 Boat ramp & ++ & + \\
\hline Gratiot Lake, MI & 5.9 & 21.3 & Isolated inland & 1 Boat ramp & ++ & ++ \\
\hline Kabetogama Lake, MN & 101.2 & 24.3 & 5-Lake interconnection & Multiple & ++++ & +++ \\
\hline Lac LaBelle, MI & 4.9 & 11.6 & Lake Superior coastal & 1 Boat ramp & +++ & ++ \\
\hline Lake Fanny Hoe, MI & 0.9 & 12.2 & $\begin{array}{l}\text { Lake Superior coastal, } \\
\text { downstream } \\
\text { connection }\end{array}$ & 1 Boat ramp & ++ & + \\
\hline Lake Gogebic, MI & 53.1 & 10.6 & Isolated inland & 5 Boat ramps & ++++ & +++ \\
\hline Lake Medora, MI & 2.8 & 9.1 & Isolated inland & 1 Boat ramp & +++ & +++ \\
\hline Long Lake, Grand Traverse County, MI & 11.6 & 24.6 & Isolated inland & 2 Boat ramps & +++ & +++ \\
\hline Loon Lake, MI & 0.4 & 11.2 & Platte River connection & 1 Boat ramp & ++ & + \\
\hline Michigamme Lake, MI & 17.6 & 22 & Michigamme River & 2 Boat ramps? & +++ & +++ \\
\hline Michigamme Reservoir, MI & 19.7 & 12.2 & Michigamme River & 8 Boat ramps, 1 canoe & +++ & +++ \\
\hline Namakan Lake, MN & 101.7 & 45.7 & 5-Lake interconnection & Multiple & ++++ & +++ \\
\hline Peavy (Reservoir) Pond, MI & 14.2 & 7.6 & Michigamme River & 2 Boat ramps, 2 canoe & ++ & + \\
\hline Platte Lake, MI & 10.2 & 27.4 & Isolated inland & 2 Boat ramps & +++ & +++ \\
\hline Portage Lake, MI & 43.7 & 14.9 & Lake Superior coastal & 5 Boat ramps & +++ & +++ \\
\hline Rainy Lake, MN & 858 & 49.1 & 5-Lake interconnection & Multiple & ++++ & +++ \\
\hline Roland Lake, MI & 1.2 & 12.2 & Isolated inland & 1 Boat ramp & +++ & +++ \\
\hline Sand Point Lake, MN & 21 & 56.1 & 5-Lake interconnection & Multiple & +++ & + \\
\hline
\end{tabular}

piles up water along the southern coastline, forcing $11-13^{\circ} \mathrm{C}$ water from Keweenaw Bay into the South Entry and Portage Lake. Simultaneously, the surge pushes warmer $\left(17-20^{\circ} \mathrm{C}\right)$ water from Portage Lake northward out the North Entry. There are two mechanisms at work: (1) surface wind stress acting along the Waterway's axis, and (2) changes in coastal lake levels that generate flow by pressure gradients (Churchill et al. 2004). On this date, the warm water exiting from the North Entry into coastal Lake Superior waters is easily discernible because the lens flows out over very cold $\left(4-7^{\circ} \mathrm{C}\right)$ upwelling hypolimnetic waters.

That the exchanges reverse and are frequent is evident when we examine long-term temperature records from North and South Entries relative to changes in prevailing winds. In Fig. 5, cold and warm-water intrusions reverse and alternate between North and South Entries. As in the Landsat 5 image (Fig. 4), during prevailing offshore winds from the southeast, warm water from Portage Lake exits from North Entry at the same time that cold water from Lake Superior penetrates the South Entry. With northwest winds, the pattern reverses, as cold coastal waters from Lake Superior enter the North Entry while warm Portage Lake waters exit the South Entry. Note that during May 1999 the water exchanges occurred 4-5 times (Fig. 5). During July through September, it is commonplace to find Bythotrephes moved into the narrow North and South Entry channels. Akin to tidal pumping, the water 


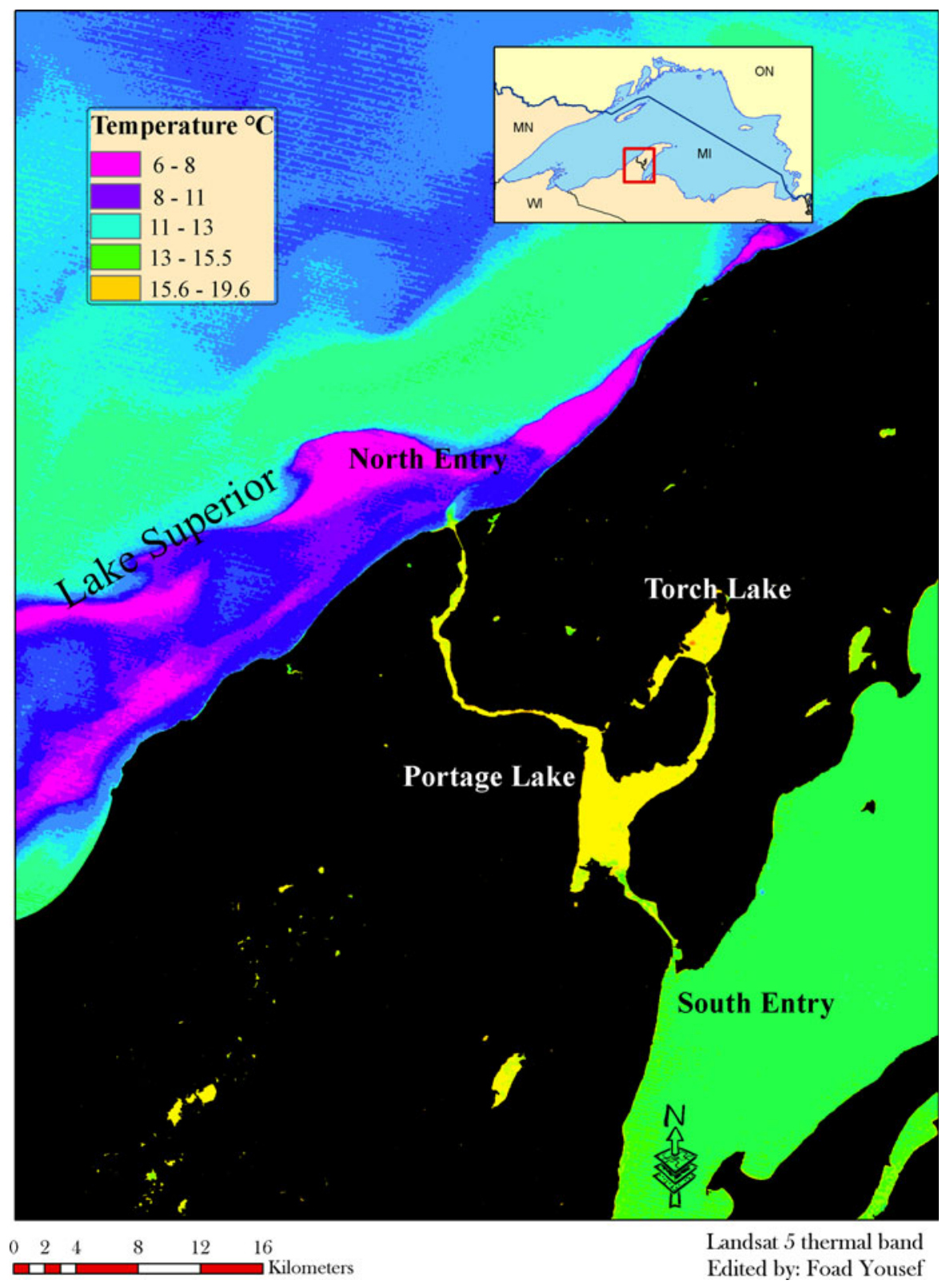

Fig. 4 Landsat 5 (band 6, temperature) image of the Keweenaw Waterway on July 5, 2009, showing water movement during a strong southeasterly wind. The wind piles up water along the southern coastline, forcing $11-13^{\circ} \mathrm{C}$ water

exchange is an important mechanism that undoubtedly aided colonization of coastal embayments around Lake Superior (e.g., Portage Lake, Lac LaBelle, Batchawana Bay, Black Bay, Nipigon Bay, Lake Nipigon) and along the coastal stretches of the other Great Lakes. from Keweenaw Bay into the South Entry. Simultaneously, the surge pushes warmer $\left(17-20^{\circ} \mathrm{C}\right)$ water out the North Entry, over the cool $\left(6-7^{\circ} \mathrm{C}\right)$ water upwelling along the northern shoreline

Although Bythotrephes are often present in North Entry and South Entry channels during AugustSeptember, self-reproducing summer populations were not established in Portage Lake until 1993, a very cool summer. Spiny cladocerans persisted until the exceptionally warm summers of 1998-1999, 

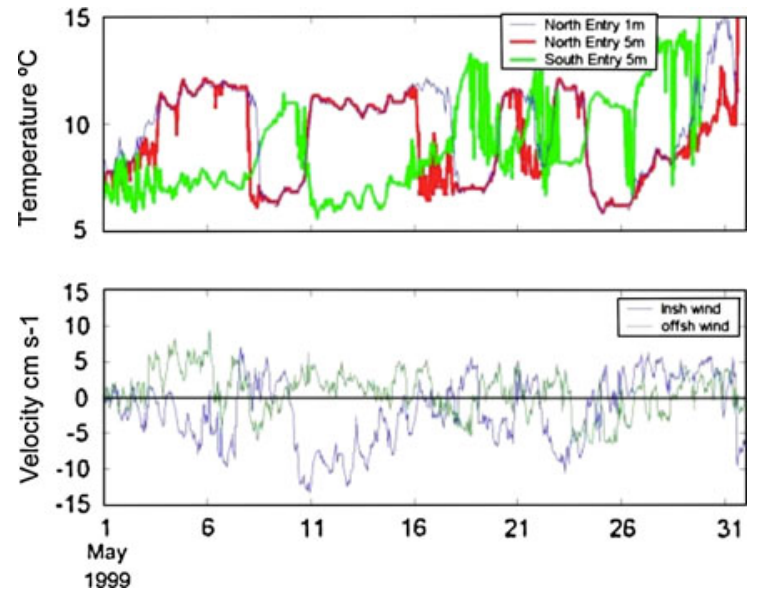

Fig. 5 Time series of temperatures at the North and South Entries of the Keweenaw Waterway through May of 1999, illustrating the frequency of water exchanges relative of prevailing wind direction and magnitude. Positive along-shore winds are upwelling favorable

when they failed to maintain populations throughout the summer and fall (Compton and Kerfoot 2004). Up to the present (2010), the species has not reestablished populations in Portage Lake, nor have populations reached Torch Lake, a step further up the inland chain (Fig. 4).

Detailed temperature records from Portage Lake revealed a serious temperature "compression" associated with summer storms that probably contributed to the species' demise in 1998 and 1999 (Fig. 6). Whereas Portage Lake was previously thought to be a permanently stratified lake (Spain et al. 1969), our investigations clearly showed it to be polymictic, despite a maximum $15.8 \mathrm{~m}$ water depth. For the 1999 series, water column mixing events are indicated when the $1 \mathrm{~m}$ (epilimnion) and $9 \mathrm{~m}$ (hypolimnion) temperatures converge (Fig. 6, arrows). During the summer "cold air outbreaks"-storms from the north with cold temperatures and strong winds-mix colder bottom waters with warmer near-surface waters. Intervening periods are characterized by rapid warming of surface waters. The counter-intuitive consequence of the cold storms is that they progressively raised the temperature of hypolimnetic waters, whereas the lessened density difference between epilimnetic and hypolimnetic waters made mixing more likely during the next storm event. Over the summer, epilimnetic waters reached a maximum temperature of $27^{\circ} \mathrm{C}$, whereas hypolimnetic waters

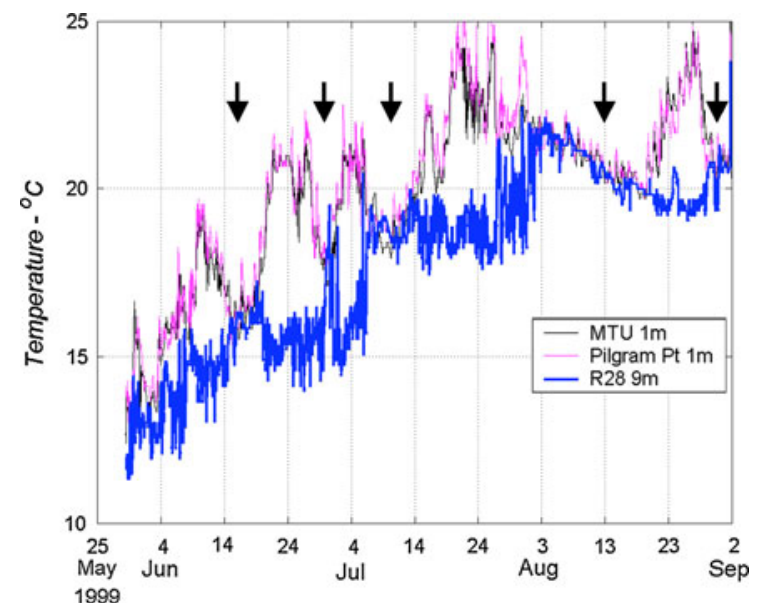

Fig. 6 Time series of Portage Lake epilimnion and hypolimnion temperatures through the spring and summer of 1999. Vertical arrows mark periodic cold-outbreak storms that mix upper and lower waters, destratifying the water column and progressively warming hypolimnetic waters. Notice by the end of summer how the temperatures of hypolimnetic waters approach the warm epilimnetic waters

increased to $24^{\circ} \mathrm{C}$. The consequences of repeated mixing were that Bythotrephes, which normally descend to the top of the thermocline to gain relief from warm epilimnetic waters, were sandwiched between 27 and $24^{\circ} \mathrm{C}$ waters, very warm relative to the preferred $14-23^{\circ} \mathrm{C}$ optimum (Yurista 1999). Physiological stress at these temperatures is very realistic, as Garton et al. (1990) found lethal effects on Bythotrephes above $25-26^{\circ} \mathrm{C}$ and Yurista (1999) indicated adverse respiration and enzyme activity impacts above $26^{\circ} \mathrm{C}$. The Portage Lake record provides a specific example of how Bythotrephes colonization in polymictic lakes is sensitive to epilimnion-hypolimnion temperature compression during exceptionally warm years.

Colonization of inland lakes via recreational boat use factors

Most of the newly colonized inland lakes (Table 1) were the relatively large, deep, cool and unproductive water bodies predicted by European occurrence (MacIsaac et al. 2000). The species had invaded one new near-park boundary lake at Sleeping Bear Dunes National Lakeshore (Big Platte Lake) in the lower Peninsula of Michigan. Downstream connection from Big Platte Lake via the Platte River led to 
incidental occurrence of spines in Loon Lake (area $=0.4 \mathrm{~km}^{2}$ ), but no evidence of an egg bank. We confirmed the presence of abundant Bythotrephes spines and eggs in two interior lakes at Pictured Rocks National Lakeshore (Beaver Lake, Grand Sable Lake) and in at least three large lakes of Voyageurs National Park (Namakan, Kabetogama, Rainy Lake). Scarce spines were found in Crane Lake (adjacent to Voyageurs), which connects to the larger lakes through a narrow channel.

Lack of invasions at Isle Royale National Park (no Bythotrephes in Siskiwit Lake, Ahmik Lake, Lake Whittlesey, Lake Richie, Beaver Lake, Lake Desor, Feldtmann Lake, Chicken Bone Lake, Sargent Lake, Lake Harvey) contrasted with rapid spread on the nearby Keweenaw Peninsula (Portage, Lac LaBelle, Fanny Hoe, Medora, Gratiot, Roland, Gerald, Gogebic lakes). Although the two areas had comparable geology, lake density, and fauna (e.g. ducks, shorebirds, fish-eating raptors, beaver, and other potential natural dispersers), they differed dramatically in powerboat access, boat visitation, baitfish use, and other protective measures. For example, although Bythotrephes is present in coastal waters around the archipeligo, only paddling craft are permitted on inland lakes, and canoes must be wiped clean during portage. Live, dead or preserved bait, or organic food bait, may not be used or possessed at any time.

The contrast between Isle Royale and the Keweenaw Peninsula underscores human-aided dispersal of Bythotrephes via launch ramp activity, i.e. fishing boats, live wells, and bait buckets (Jarnagin et al. 2000). Since no motorized boats are allowed on Isle Royale National Park lakes, visitation was scored as zero. The number of boats on other lakes in summer was ranked according to an arbitrary 4-point scale in Table 1 (1, only occasional; 2 a few; 3 some, 4 numerous).

Fish ingestion of Bythotrephes and diapausing eggs: size-dependent factors

In inland Lake Michigamme and several lakes in Voyageurs National Park, parthenogenetic reproduction appears to dominate throughout much of the spring, summer, and early fall. However, ingestion of Bythotrephes by fish is very size- and age-dependent, helping explain the variability of original consumption observations. The size- and age-dependency underlies the evolution of the large tail spine relative to YOY fish, but also emphasizes why a second adaptation (viable gut passage of diapausing eggs) is necessary to counter vulnerability to large YOY and year-1 fish.

We have observed similar critical size-dependant relationships for perch (Perca flavacans), bluegill (Lepomis machrochirus), and spot-tail shiners (Notropis hudsonius), the latter a common local baitfish (Jarnagin et al. 2004; Compton and Kerfoot 2004). If the number of Bythotrephes consumed by yellow perch is plotted as a function of total length, either for Lake Michigamme or Voyageurs National Park samples, there are three critical size intervals (Fig. 7). The first size interval includes small YOY $(25-60 \mathrm{~mm})$. The small YOY fish are usually pelagic-feeding, as determined by other cladoceran prey in stomachs (Daphnia, Diaphanosoma, Ceriodaphnia, Bosmina). YOY fish avoid consuming Bythotrephes, presumably because of the caudal spine (Jarnagin 1998; Jarnagin et al. 2004). In the second size interval (60-110 mm), the number of Bythotrephes consumed dramatically increases. This size range of fish consists of a mixture of fast-growing YOY and year-1 fish. Using scale growth ring patterns to separate the two age classes, July 9 to August 1 sub-samples contained YOY of (mean $\pm 95 \%$ CL) $62 \pm 3$ to $65 \pm 2.4 \mathrm{~mm}$ total length, whereas year-1 fish had mean total lengths of $89 \pm 4$ to $94 \pm 4 \mathrm{~mm}$. Between 80 and $110 \mathrm{~mm}$, year1 fish consumed a mean of 20-50 Bythotrephes/fish, with some individuals containing as high as $80-120$ Bythotrephes/fish. Of 22 perch from Lake Michigamme found to have consumed Bythotrephes, 6 fish (27\%) were found with a total of 22 diapausing eggs in their guts. In the third interval, beyond $110 \mathrm{~mm}$, year-1 young perch "switched" to alternative prey and feeding behavior, concentrating on bigger benthic organisms (corixids, amphipods, dragonfly larvae), largely avoiding Bythotrephes. Thus, for Bythotrephes in lakes with perch, there is a narrow size "window" of vulnerability, yet fish may contain appreciable numbers of diapausing eggs.

The same basic body size pattern was also evident for perch collected from Voyageurs National Park lakes. Fish in June and early July are small (30-40 mm), pelagic-feeding (Daphnia, Ceriodaphnia, Bosmina in guts), and only occasionally ingest a Bythotrephes. However, later in the year, in late JulyAugust, fish between 60 and $120 \mathrm{~mm}$ will ingest 


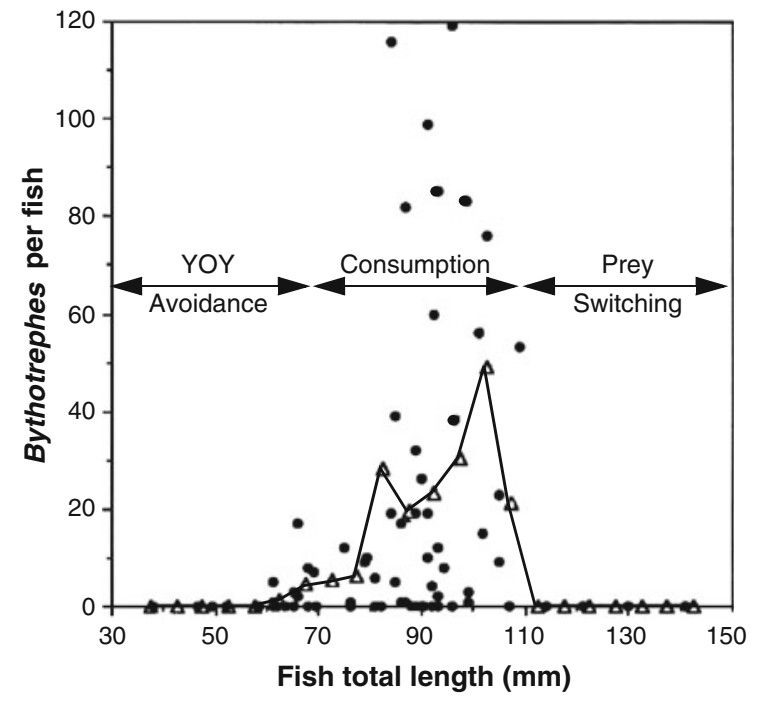

Fig. 7 Size relationships of Bythotrephes consumed by yellow perch, plotted as a function of fish total length (1996 samples, $n=74$ ). Dots indicate totals from individual fish stomachs, whereas triangles give means for each 5-mm size interval. We emphasize that small perch fail to consume Bythotrephes because of the spine, whereas larger year-1 fish switch to alternative prey (larger benthic species)

numerous Bythotrephes and can carry as many as 20-60 diapausing eggs in their guts (Fig. 8a). Based on scale analysis, Voyageurs fish between 80 and $110 \mathrm{~mm}$ total length were also often year-1.

How fish disperse diapausing eggs

with-in and between lakes

In Lake Michigan, Bythotrephes does not over-winter in pelagic waters, emerges from diapausing eggs in May-June, and is epilimnetic, often with a dual population maximum (July, August). The species mean depth ranges between 10 and $30 \mathrm{~m}$, with only weak reported diel vertical migration during midsummer, although there is deep displacement during fall (Lehman and Cáceres 1993). Pelagic population dynamics were followed separately from 1998 to 2000, with the 2,000 results published (Pothoven et al. 2003). According to Pothoven, mean offshore abundance ranged between 278 and 570 individuals $\mathrm{m}^{-2}$ surface area from July to September, resembling abundance values from spatial transects along southeastern transects between 1987 and 1998 (Cavaletto et al. 2010).

Because of its large size (3rd largest area in the world for a freshwater lake), the number of
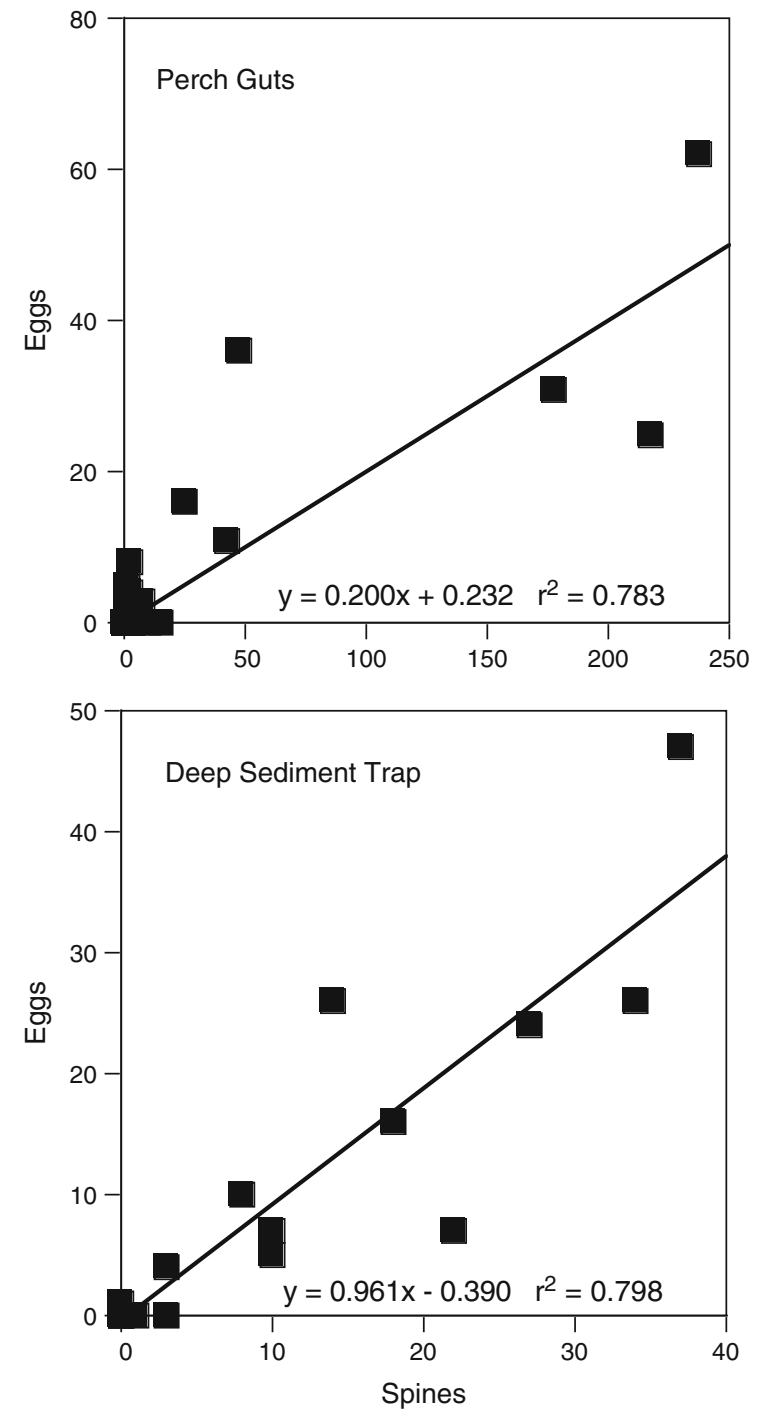

Fig. 8 A close association between eggs and spines: a relationship between diapausing eggs and spines in the guts of perch collected from Voyageurs National Park, summer of 2009, and b between diapausing eggs and spines in sediment traps, Lake Michigan 1998-2001

Bythotrephes diapausing eggs deposited during a year in Lake Michigan could be very large, making this a primary source lake for overland dispersal. For example, deep-water traps in 2000-2001 (Table 2) collected a yearly mean total of $157 \pm 38 \mathrm{eggs}_{\mathrm{grap}}{ }^{-1}$, which is equivalent to $493 \pm 122 \mathrm{eggs} \mathrm{m}^{-2}$. During 20002001, Pothoven et al. (2003) reported that Bythotrephes were more abundant and more likely to be sexual in offshore deep waters, rather than in shallow nearshore waters. We found that diapausing eggs began to settle into traps in July and continued through 
October. Absolute numbers deposited into shallowwater traps were consistently fewer than in deep-water traps, also suggesting that population size was larger offshore in deeper waters. During 3 years of study, deep-water tallies (>100 m water depth) for egg deposition ranged between 18 and 187 eggs trap $^{-1}$ year ${ }^{-1}$ at offshore sites $\left(92 \pm 67\right.$ eggs $\operatorname{trap}^{-1}$ year $^{-1}$, $n=14$ traps), whereas nearshore tallies $(<100 \mathrm{~m}$ depth) ranged between 1 and 21 eggs trap $^{-1}$ year ${ }^{-1}$ ( $7 \pm 8$ eggs/trap/year; $n=23$ ). These values translate into $289 \pm 210 \mathrm{eggs} \mathrm{m}^{-2}$ for deep-water traps and $22 \pm 25 \mathrm{eggs} \mathrm{m}^{-2}$ for nearshore traps. Since the area of Lake Michigan is $57,800 \mathrm{~km}^{2}$, with $63 \%$ of the area nearshore $(<100 \mathrm{~m})$ and $37 \%$ deep-water $(>100 \mathrm{~m})$, the mean yearly deposition of diapausing eggs is estimated as $7.0 \times 10^{12}$ ( 7 trillion), an enormous number.

In inland lakes such as Michigamme and Voyageurs National Park, water column sampling of pelagic zooplankton usually takes place between May and September, often missing end-of-season diapausing egg production periods. Yet we found that females begin to carry diapausing eggs as early as July, although the frequency of diapausing eggs greatly increased by fall. The Michigamme and Voyageurs seasonal patterns seemed similar to ones reported from Harp Lake (Yan and Pawson 1997). In the central basin of Lake Michigamme, the estimated deposition of diapausing eggs in 1995 and 1996 was $143 \pm 102 \mathrm{~m}^{-2}$ and $212 \pm 61 \mathrm{~m}^{-2}$. Projecting those deposition rates over the entire lake basin yields total depositions of 2.5-3.7 billion eggs year ${ }^{-1}$, again a very large number.

In deep-water Lake Michigan traps, there was a high incidence of broken spines ( $>70 \%)$ and an equally high correlation between egg and spine flux (Fig. 8b; $\left.y=0.961 x-0.390, r^{2}=0.798, n=14, P<0.01\right)$. The high correlations suggested that both items could be arriving in fish fecal pellets (Figs. 8b, 9, 10). Although fluxes of spines and eggs into shallow-water traps ( $<50 \mathrm{~m}$ water depth) were lower, the ratio of eggs to spines was also high and significantly correlated ( $\left.y=0.813 x-0.178, r^{2}=0.594, n=22, P<0.01\right)$.

In deep-water Lake Michigan traps, often there were two peaks of spine deposition, late summer (mid-August) and late fall (October), the latter

Table 2 Diapausing egg deposition time series for representative Lake Michigan deep-water sequential sediment traps, using programmed 2-week rotation interval

\begin{tabular}{lcccccc}
\hline Date & SB T12-100 & SB T12-155 & GH T27-100 & GH4 T27-100 & NB T29-200 & NB T29-100 \\
\hline $7 / 1 / 00$ & 0 & 0 & 0 & 0 & 0 & 0 \\
$7 / 15 / 00$ & 0 & 0 & 2 & 0 & 0 & 7 \\
$7 / 29 / 00$ & 0 & 7 & 16 & 4 & 47 & 47 \\
$8 / 12 / 00$ & 0 & 13 & 5 & 4 & 26 & 40 \\
$8 / 26 / 00$ & 1 & 5 & 16 & 4 & 16 & 21 \\
$9 / 9 / 00$ & 21 & 5 & 1 & 4 & 5 & 11 \\
$9 / 23 / 00$ & 3 & 3 & 12 & 4 & 10 & 17 \\
$10 / 7 / 00$ & 14 & 13 & 30 & 8 & 26 & 22 \\
$10 / 21 / 00$ & 90 & 57 & 52 & 36 & 24 & 3 \\
$11 / 4 / 00$ & 49 & 26 & 8 & 12 & 4 & 0 \\
$11 / 18 / 00$ & 9 & 4 & 5 & 0 & 0 & 0 \\
$12 / 2 / 00$ & 0 & 1 & 0 & 0 & 0 & 0 \\
$12 / 16 / 00$ & 0 & 0 & 0 & 0 & 1 & 0 \\
$12 / 30 / 00$ & 0 & 0 & 0 & 0 & 0 & 2 \\
$1 / 13 / 01$ & 0 & 0 & 0 & 0 & 0 & 0 \\
$1 / 27 / 01$ & 0 & 0 & 0 & 0 & 173 & 187 \\
$2 / 10 / 01$ & 0 & 134 & 171 & 88 & \\
Total & 187 & 0 & 0 & 0 & \\
\hline
\end{tabular}

Yearly mean number $( \pm \mathrm{SD})$ of eggs deposited (2000-2001) is $157 \pm 38.8$ eggs per trap or $493 \pm 122$ eggs per $\mathrm{m}^{2}(n=6)$. See Fig. 3 for trap locations (T12, T27) in southern Lake Michigan 
Fig. 9 Diapausing eggs and spines that settle into Lake Michigan sequential sediment traps. Counts of spines and eggs are given for 2-week collections and corresponding fluxes (numbers $\mathrm{m}^{-2}$ days $^{-1}$ ). Note the higher correlation between spines and eggs in the deeper traps, suggesting arrival in fecal pellets

coinciding with population collapse (Fig. 9). The broken condition of the spines (primary folded spine, sheared off barbs) in traps indicated that most spines had passed through fish guts, resembling breakage patterns observed in laboratory feeding experiments (Jarnagin et al. 2004).

Some interesting calculations can be done to illustrate fish electivity for egg-carrying adults. Egg-carrying adults possess two attributes that favor conspicuousness: large size and opaque eggs. Given the reported offshore brood size of diapause-egg carrying females in Lake Michigan (5.04 eggs per female; Pothoven et al. 2003), the total number of eggs deposited in a selected set of deep-water traps during 2000 (Table 2) was equivalent to deposition of 187 egg-carrying females. Dividing that number by the total number of spines (dead individuals, 1,155), allows us to indirectly calculate that $16 \%$ of individuals ingested by fish were diapause-egg carrying females. This ratio is much higher than the mean percentage of diapause egg-carrying females found in August waters (0-15\%, mean ca. 2-7\%; Pothoven et al. 2003), suggesting positive electivity of fish towards the more conspicuous, larger-bodied eggcarrying females. Fish ingestion preference for large, egg-carrying adults is consistent with previous observations (Jarnagin et al. 2000, 2004).

\section{Discussion}

The recent Bythotrephes distribution suggests rapid expansion from primary sources (Great Lakes coastal waters) to inland lakes within a northern latitudinal band of lake temperatures. The observed summer temperature range of colonized lakes $\left(14-26^{\circ} \mathrm{C}\right)$ matches closely with previously observed Old World and New World preferred temperature optimum of 14-23 ${ }^{\circ} \mathrm{C}$ (Garton et al. 1990; Grigorovich et al. 1998; Yurista 1999; MacIsaac et al. 2000). Along the southern range, we have emphasized physiological stress above $24-26^{\circ} \mathrm{C}$. Southern Minnesota lakes
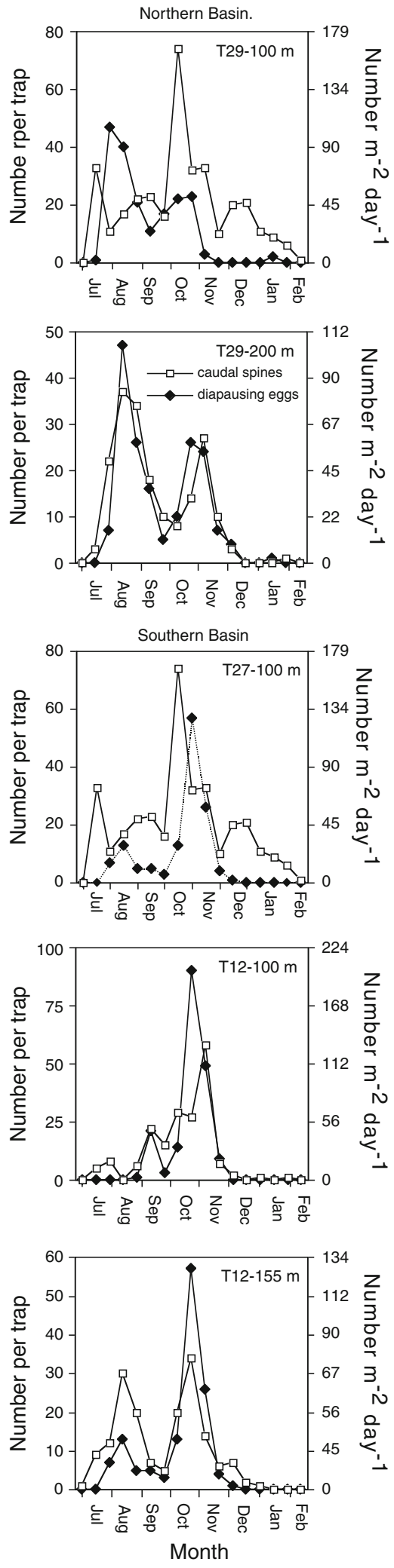


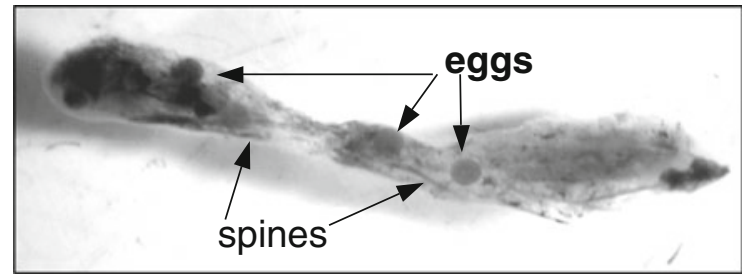

Fig. 10 A fecal pellet from fish aquarium feeding experiments with Bythotrephes, showing broken spines and enclosed diapausing eggs

routinely experience maximum summer temperatures above $26^{\circ} \mathrm{C}$ (Hondzo and Stefan 1993). In Lake Erie, Garton et al. (1990) found lethal effects on Bythotrephes above $25-26^{\circ} \mathrm{C}$, whereas Yurista (1999) indicated adverse respiration and enzyme activity impacts for Lake Michigan Bythotrephes above $26^{\circ} \mathrm{C}$. For the most part, MacIssac et al.'s (2000) characterization of Bythotrephes' habitat as "large, deep, clear basins with relatively low benthic water temperature during summer" seems to fit the observed inland colonization pattern.

In Portage Lake, we provided an example of how, in warm summers (1998-1999), repeated storms collapse vertical temperature strata in polymictic lakes by increasing hypolimnetic temperatures. Our "thermal compression" hypothesis would apply anywhere where there are warm epilimnetic waters and periodic water column mixing.

Calculations of diapause egg production in Lake Michigan suggest intense propagule pressure along southern coastlines, yet little observed inland small lake colonization. Bythotrephes evidently has difficulty colonizing small southern inland lakes that experience epilimnetic water temperatures in the range $26-30^{\circ} \mathrm{C}$, as evidenced by the lack of inland spread across southern Michigan, Wisconsin, and Minnesota. However, because of their vast size, the relatively lower epilimnetic temperatures and clear waters of the Great Lakes allow population growth of Bythotrephes even in southern latitudes.

Yet even during the northern range extension, Bythotrephes has disappeared from some lakes (e.g. Fish and Boulder Lakes, Minnesota, Branstrator et al. 2006; Portage Lake, Dead River Impoundment, Spectacle Lake, Michigan), emphasizing that gains and losses are occurring simultaneously, although gains are dominating. Eventually, the geographic pattern will allow construction of a "dispersal kernal" and prediction of a rate of spread (dispersal "front" or "wave"). Construction of "dispersal kernels" has been described by Lewis (1997) as a means of quantifying dispersal from a primary source. A relevant example in lake studies is Havel's study of Daphnia lumholzi dispersal (Havel et al. 2002; Havel and Shurin 2004), where the suspected dispersal vector was also small fishing boats spreading Daphnia in live wells and bait buckets.

Based on the contrast between Isle Royale National Park and Keweenaw Peninsula lakes, visitation frequency, powerboat access, and prevention measures appear to be important variables influencing recent inland geographic dispersal of Bythotrephes from coastal regions of the Great Lakes. The evidence from Isle Royal versus Keweenaw Peninsula contrast is admittedly indirect, yet reveals mechanisms for overland dispersal. We emphasize that the interaction between fish and diapausing eggs is a potentially crucial component in geographic spread. Bythotrephes utilize at least three size-dependent protective traits (two morphological, one behavioral): (1) an extremely large and long tail spine that protects against YOY fish (Barnhisel 1991a, b; Barnhisel and Harvey 1995; Straile and Haelbich 2000), (2) an unusually large and thick-shelled diapausing egg that can pass through fish guts in viable condition (Jarnagin et al. 2000, 2004), and (3) vertical migration of embryo-carrying adults to a refuge layer down below the photic zone, but above the thermocline during the day (Yan et al. 2001; Manca and DeMott 2009).

The presence of large tail spines allows Bythotrephes to co-occur with the younger, more numerous and greatest biomass class of potential fish consumers. Although reproductively mature female Bythotrephes are often not the most abundant instars in the water column, large and more conspicuous (especially diapause-egg carrying adults) are preferentially susceptible to ingestion by larger visually feeding fishes (Jarnagin et al. 2000, 2004). Vulnerability to the less numerous larger fish is offset by viable gut passage of diapausing eggs. We emphasize that many late-summer Bythotrephes carry diapausing eggs, making this a key within- and between-lake dispersal vector.

The marked contrast between lack of successful colonization on Isle Royal National Park compared to 
the Keweenaw Peninsula argues that natural biota are not the major dispersers of Bythotrephes to inland lakes, at least at the present time. Although resistant diapausing eggs are capable of passing through birds guts in viable condition (Charalambidou et al. 2003), we expect that encounters between birds and Bythotrephes are limited in nature because Bythotrephes are normally deep in the water column. Moreover, the eggs are large, heavy, and settle rapidly (Jarnagin et al. 2000, 2004) unless consumed by fish.

Both Yan et al. (2001) and Jarnagin et al. (2004) suggested that Bythotrephes abundance in Harp Lake, Ontario, Canada, and Lake Michigamme, Michigan, appeared associated with the thickness of a low-light, moderate temperature $\left(12-18^{\circ} \mathrm{C}\right)$ refuge from planktivorous fish. Branstrator et al. (2006) stressed that invasion success was favored by the presence of a deep-water, low-light but well-oxygenated refuge in many of the Minnesota lakes. Recently, Young et al. (2009) argued that in small lakes, including Harp Lake, the "refuge" does not exist, as there is sufficient illumination for planktivorous fish feeding at the metalimnion. Yet in the highly stained waters of Lake Michigamme, such a vertical configuration clearly exists, protecting Bythotrephes against visual predation by perch (Jarnagin 1998; Jarnagin et al. 2004). In relatively large Lake Maggiori, Italy, Manca and DeMott (2009) argued that global climate change promotes earlier seasonal establishment and longer duration of the light "refuge", increasing Bythotrephes numbers. However, in Lake Maggiori, increase in spiny cladoceran numbers was also related to long-term reduction of planktivorous fish density, a consequence of phosphorus abatement.

Fish ingestion and dispersal of diapausing eggs solves a dilemma in Lake Michigan posed by Yurista (1997) and applies to other large lakes. Yurista found high concentrations of diapausing eggs in deep (>60 m) sediments $\left(2,500-5,000\right.$ eggs m$\left.^{-2}\right)$ and much lower concentrations in nearshore sediments (100-600 eggs $\mathrm{m}^{-2}$ ). However, temperature-hatching cues favored recruitment only from nearshore sediments. The sole mechanism that Yurista could imagine to redistribute eggs was shallow sediment resuspension and redeposition, which he dismissed as unlikely and that acted in the opposite direction to onshore drift. However, with fish ingestion of diapausing eggs, there is likelihood of yearly spread from pelagic waters back into nearshore waters, continually mixing gene pools and increasing the chances for early hatching.

Several species of lake fish are known to consume large numbers of Bythotrephes: spottail shiners (Notropis hudsonius), alewife (Alosa pseudoharengus), rainbow smelt (Osmersus mordax), and lake herring (Coregonus artedi) (Hartman et al. 1992; Coulas et al. 1998; Parker et al. 2001; Young et al. 2009). Yellow perch (Perca flavescens) have long been recognized to ingest Bythotrephes (Baker et al. 1992; Pothoven et al. 2000; Jarnagin et al. 2004). With most fishes, ingestion is decidedly size-specific. If YOY fish are larger than $80-90 \mathrm{~mm}$ or are year-1 class, large numbers of spiny cladocerans can be consumed (Baker et al. 1992; Jarnagin 1998; Pothoven et al. 2000). In Lake Michigan, for fish $>100 \mathrm{~mm}$, Bythotrephes was found to be a dominant prey item, achieving a mean of 48 (range 0-323) per stomach (Baker et al. 1992).

Given the high percentages of broken spines (60-75\%) being deposited with eggs into sediment traps, we conclude that the highest mortality for Bythotrephes during the regular season comes from fish predation and that diapausing eggs are routinely dispersed around lakes from July through September, released in fecal pellets (Jarnagin et al. 2004). Although bait bucket transfer has long been suspected (Ludwig and Leitch 1996), viable diapausing eggs create another wrinkle. Because of this feature, baitfish provide a simple vector for movement of eggs from one lake to another (Jarnagin et al. 2000; Compton and Kerfoot 2004). We stress that this process is nothing more than an extension of the within-lake diapausing egg dispersal process routinely occurring in individual lakes. If fish are seined or hand-caught in one lake and then transferred to another lake, they will defecate eggs into bait buckets, live wells, or directly into the second lake. If fish are placed in live wells, where they defecate eggs, and the eggs flushed into another lake, then transfer will also take place. Given the relative high ratio of eggs to spines in fish guts (Figs. 8b, 9, 10), and the high absolute numbers of eggs in some fish (Fig. 8a), the likelihood of exceeding Allee effect numbers for successful colonization is relatively high. For example, under the right conditions, a single fish could transfer large numbers of eggs (10-160). 
Because of viral hemorrhagic septicemia, commercial baitfish operations are now much more careful with rearing and distribution procedures. However, many fishermen seine their own baitfish. Practical control measures for slowing down or elimination of between-lake transfer include relatively simple steps, such as on-site rinsing of live wells, restricting transfer of certain baitfish species, or holding baitfish for $24 \mathrm{~h}$ (defecation period). For example, the kind of baitfish makes a difference. Spot-tail shiners (Notropis hudsonius) and perch (Perca flavescens) are lake dwellers known to ingest large numbers of Bythotrephes, whereas chubs (Semotilus atromaculatus) and emerald shiners (Notropis atherinoides) can be stream dwellers that are unlikely to ingest spiny cladocerans.

In addition to preventative measures at Isle Royale National Park and interior lakes in Voyageurs National Park, we also encountered control efforts by lake associations, e.g. at Little Glen Lake, near Sleeping Bear Dunes National Lakeshore. Lake Association members had established an inspection station near the only boat access ramp for all incoming boats. At the station they voluntarily washed down (high pressure hose) all boats, rinsed live wells, and examined all fishing lines and anchor ropes. At the time of our visit (30 June 2008) they had recorded 640 boats inspected that year, and reported finding Bythotrephes on fishing line in the summer of 2007. Although Little Glen Lake is large and in close proximity to a Bythotrephes source (Lake Michigan shoreline), there was no evidence for Bythotrephes or zebra mussels, suggesting that procedures were effective.

Acknowledgments Study of Lakes Superior and Michigan was funded from NSF OCE-9726680 and OCE-9712872 to W.C.K., OCE-9712889 to J. Churchill. Geographic survey sampling and Park studies in the national parks during 2008-2010 were funded by a grant from the National Park Service Natural Resource Preservation Program GLNF CESU Task Agreement No. J6067080012. Lucille Zelazny aided figure preparation.

Open Access This article is distributed under the terms of the Creative Commons Attribution Noncommercial License which permits any noncommercial use, distribution, and reproduction in any medium, provided the original author(s) and source are credited.

\section{References}

Alexander ML, Hotchkiss SC (2009) Bosmina remains in lake sediment as indicators of zooplankton community composition. J Paleolimnol 43(1):51-59

Baker EA, Tolentino SA, McCornish TS (1992) Evidence for yellow perch predation on Bythotrephes cederstroemi in southern Lake Michigan. J Great Lakes Res 18(1):190-193

Barbiero RP, Tuchman ML (2004) Changes in the crustacean communities of Lakes Michigan, Huron and Erie following the invasion of the predatory cladoceran Bythotrephes longimanus. Can J Fish Aquat Sci 61(11):21112125

Barnhisel DR (1991a) The caudal appendage of the cladoceran Bythotrephes cederstroemi as defense against young fish. J Plankton Res 13:529-537

Barnhisel DR (1991b) Zooplankton spine induces aversion in small fish predators. Oecologia 88:444-450

Barnhisel DR, Harvey HA (1995) Size-specific fish avoidance of the spined crustacean Bythotrephes: field support for laboratory predictions. Can J Fish Aquat Sci 52:768-775

Barnhisel DR, Kerfoot WC (1994) Modeling young-of-the-year fish response to an exotic invertebrate: direct and indirect interactions. In: Stouder D, Fresh K, Feller R (eds) Theory and applications of fish feeding ecology. University of South Carolina Press, Columbia, pp 315-328

Berg DJ, Garton DW (1988) Seasonal abundance of the exotic predatory cladoceran, Bythotrephes cederstroemi, in western Lake Erie. J Great Lakes Res 14(4):479-488

Bollens SM, Cordell JR, Avent S, Hooff R (2002) Zooplankton invasions: a brief review, plus two case studies from the northeast Pacific Ocean. Hydrobiologia 480:87-110

Boudreau SA, Yan ND (2004) Auditing the accuracy of a volunteer-based surveillance program for an aquatic invader Bythotrephes. Environ Monit Assess 91(1-3):17-26

Branstrator DK, Lehman JT (1996) Evidence for predation by young-of-the-year alewife and bloater chub on Bythotrephes cederstroemi in Lake Michigan. J Great Lakes Res 22:917-924

Branstrator DK, Brown ME, Shannon LJ, Thabes M, Heimgartner K (2006) Range expansion of Bythotrephes longimanus in North America: evaluating habitat characteristics in the spread of an exotic zooplankter. Biol Invasions 8(6):1367-1379. doi:10.1007/s10530-005-5278-7

Cavaletto JF, Vanderploeg HA, Pichlovea-Ptacnnikova R, Pothoven SA, Liebig J, Fahnenstiel G (2010) Temporal and spatial separation allows coexistence of predatory cladocerans: Leptodora kindtii, Bythotrephes longimanus and Cercopagis pengoi in southeastern Lake Michigan. J Great Lakes Res 36:65-73

Charalambidou I, Ketelaars AM, Santamaria L (2003) Endozoochory by ducks: influence of developmental stage of Bythotephes diapause eggs on dispersal probability. Divers Distrib 9:367-374

Churchill JH, Kerfoot WC (2007) The impact of surface heat flux and wind on thermal stratification in Portage Lake, Michigan. J Great Lakes Res 33:143-155 
Churchill JH, Kerfoot WC, Auer MT (2004) Exchange of water between the Keweenaw Waterway and Lake Superior: characteristics and forcing mechanisms. J Great Lakes Res 30(Supplement 1):55-63

Compton JA, Kerfoot WC (2004) Colonizing inland lakes: consequences of YOY fish ingesting the spiny cladoceran (Bythotrephes cederstroemi). J Great Lakes Res 30(Supplement 1):315-326

Coulas RA, MacIsaac HJ, Dunlop W (1998) Selective predation on an introduced zooplankton (Bythotrephes cederstroemi) by lake herring (Coregonus artedii) in Harp Lake, Ontario. Freshw Biol 40:343-355

Cullis K, Johnson G (1988) First evidence of the cladoceran Bythotrephes cederstroemii Shoedler in Lake Superior. J Great Lakes Res 14:524-525

Eadie BJ (1997) Probing particle processes in Lake Michigan using sediment traps. Water Air Soil Pollut 99:133-139

EPA (2010) National lakes assessment report. Water.epa.gov/ type/lakes/lakesurvey_index.cfm

Garton DW, Berg DJ, Fletcher RJ (1990) Thermal tolerance of the predatory cladocerans Bythotrephes cederstroemi and Leptodora kindtii relationship to seasonal abundance in Lake Erie. Can J Fish Aquat Sci 47:731-738

Grigorovich IA, Pashkova OV, Gromova YF, van Overdijk CDA (1998) Bythotrephes longimanus in the Commonwealth of Independent States: variability, distribution and ecology. Hydrobiologia 379(1-3):183-198

Hall RI, Yan ND (1997) Comparing the annual population growth estimates of the exotic invader Bythotrephes using sediment and planktonic records. Limnol Oceanogr 42:112-120

Hartman KJ, Vondracek B, Parrish DL, Muth KM (1992) Diets of emerald and spottail shiners and potential interactions with other western Lake Erie planktivorous fishes. J Great Lakes Res 18:43-50

Havel JE, Shurin JB (2004) Mechanisms, effects, and scales of dispersal in freshwater zooplankton. Limnol Oceanogr 49(4, part 2):1229-1238

Havel JE, Shurin JB, Jones JR (2002) Estimating dispersal from patterns of spread: Spatial and local control of invasion by Daphnia lumholtzi in Missouri lakes. Ecology 83:3306-3318

Hoffman JC, Smith ME, Lehman JT (2001) Perch or plankton: top-down control of Daphnia by yellow perch (Perca flavescens) or Bythotrephes cederstroemi in an inland lake? Freshw Biol 46:759-775

Hondzo M, Stefan HG (1993) Regional water temperature characteristics of lakes subjected to climate change. Clim Change 24:187-211

Jarnagin ST (1998) Direct and indirect estimates of death rates and predator-mediated dispersal of Bythotrephes cederstroemi. $\mathrm{PhD}$ thesis, Michigan Technological University

Jarnagin ST, Swan BK, Kerfoot WC (2000) Fish as vectors in the dispersal of Bythotrephes cederstroemi: diapausing eggs survive passage through the gut. Freshw Biol 43:579-589

Jarnagin ST, Kerfoot WC, Swan B (2004) Zooplankton life cycles: direct documentation of pelagic births and deaths relative to diapausing egg production. Limnol Ocean 49:1317-1332
Keilty TJ (1988) A new biological marker layer in the sediments of the Great Lakes: Bythotrephes cederstroemi (Schoedler) spines. J Great Lakes Res 14:369-371

Kerfoot WC, McNaught AS, Jarnagin ST (2000) Invertebrate predators and fish: biogeographic patterns and fish dispersal of resting eggs. Verh Int Verein Limnol 27:18411850

Kerfoot WC, Budd JW, Churchill JH, Chen C (2009) Metacommunity perspective on zooplankton communities in Lake Superior. In: Munawar M, Munawar IF (eds) State of Lake Superior. Ecovision world monograph series. Aquatic Ecosystem Health and Management Society, Canada, pp 361-400

Lehman JT (1991) Causes and consequences of the cladoceran dynamics in Lake Michigan. Implications of the species invasion by Bythotrephes. J Great Lakes Res 17:437-445

Lehman JT, Branstrator DK (1995) A model for growth, development and diet selection by the invertebrate predator Bythotrephes cederstroemi. J Great Lakes Res 21(4):610-619

Lehman JT, Cáceres CE (1993) Food-web responses to species invasion by a predatory invertebrate: Bythotrephes in Lake Michigan. Limnol Oceanogr 38:879-891

Lewis MA (1997) Variability, patchiness, and jump dispersal in the spread of an invading population. In: Tilman D, Kareiva P (eds) Spatial ecology: the role of space in population dynamics and interspecific interactions. Princeton University Press, Princeton, pp 46-69

Ludwig HR Jr, Leitch JA (1996) Interbasin transfer of aquatic biota via angler's bait buckets. Fisheries 21:14-18

MacIsaac HJ, Ketelaars HAM, Grigorovich IA, Ramcharan C, Yan ND (2000) Modeling Bythotrephes longimanus invasions in the Great Lakes basin based on its European distribution. Arch Hydrobiol 149:1-21

MacIsaac HJ, Borbely JVM, Muirhead J, Graniero PA (2004) Backcasting and forecasting biological invasions of inland lakes. Ecol Appl 14(3):773-783

Magnuson JJ, Meisner JD, Hill DK (1990) Potential changes in thermal habitat of Great Lakes fish after global climate warming. Trans Am Fish Soc 119(2):254-264

Manca M, DeMott WR (2009) Response of the invertebrate predator Bythotrephes to a climate-linked increase in duration of a refuge from fish predation. Limnol Oceanogr 54(6, part 2):2506-2512

Meisner JD, Goddier JL, Regier HA, Shuter BJ, Christie WJ (1987) An assessment of the effects of climate warming on Great Lakes Basin fishes. J Great Lakes Res 13(3):340-352

Mills EL, O' Gorman R, DeGisi J, Herberger RF, House RA (1992) Food of the alewife (Alosa pseudoharengus) in Lake Ontario before and after the establishment of Bythotrephes cederostroemi. Can J Fish Aquat Sci 49:2009-2019

Mills EL, Leach JH, Carlton JT, Secor CL (1993) Exotic species in the Great Lakes: a history of biotic crises and anthropogenic introductions. J Great Lakes Res 19:1-54

Muzzi RW, Eadie BJ (2002) The design and performance of a sequencing sediment trap for lake research. Mar Technol Soc J 36(2):23-28

Parker SL, Rudstam LG, Mills EL (2001) Retention of Bythotrephes spines in the stomachs of eastern Lake Erie rainbow smelt. Trans Am Fish Soc 130:988-994 
Pothoven SA, Nalepa TF, Brandt SB (2000) Age-0 and Age-1 yellow perch diet in southeastern Lake Michigan. J Great Lakes Res 26(2):235-239

Pothoven SA, Fahnenstiel GL, Vanderploeg HA (2001) Population dynamics of Bythotrephes cederstroemi in south-east Lake Michigan 1995-1998. Freshw Biol 46:1491-1503

Pothoven SA, Fahnenstiel GL, Vanderploeg HA (2003) Population characteristics of Bythotrephes in Lake Michigan. J Great Lakes Res 29(1):145-156

Ricciardi A (2001) Facilitative interactions among aquatic invaders: is an "invasional meltdown" occurring in the Great Lakes? Can J Aquat Sci 58:2513-2525

Ricciardi A (2006) Patterns of invasion in the Laurentian Great Lakes in relation to changes in vector activity. Divers Distrib 12:425-433. doi:10.1111/j.1366-9516. 2006.00262.x

Sandgren CD, Lehman JT (1990) Response of chlorophyll- $a$, phytoplankton, and microzooplankton to the invasion of Lake Michigan by Bythotrephes. Verh Int Ver Limnol 24:386-392

Schulz KL, Yurista PM (1995) Diet composition from allozyme analysis in the predatory cladoceran Bythotrephes cederstroemi. Limnol Oceanogr 40(4):821-826

Schulz KL, Yurista PM (1999) Implications of an invertebrate predator's (Bythotrephes cederstroemi) atypical effects on a pelagic zooplankton community. Hydrobiologia 380:179-193

Spain JD, Drown DB, Yanko JM (1969) The use of concentrations of electrolytes and naturally fluorescent materials to study water mass movements in a freshwater "estuary". In: Proceedings of 12th conference on Great Lakes Research, International Association Great Lakes Research, pp 723733

Straile D, Haelbich A (2000) Life history and multiple antipredator defenses of an invertebrate pelagic predator, Bythotrephes longimanus. Ecology 81(1):150-163

USGS (2010) Bythotrephes longimanus factsheet. http://nas.er. usgs.gov/queries/factsheet.aspx?SpeciesID $=162$

Wahlstrom E, Westman E (1999) Planktivory by the predacious cladoceran Bythotrephes longimanus: effects on zooplankton size structure and abundance. Can J Fish Aquat Sci 56:1865-1872

Weisz EJ, Yan ND (2010) Relative value of limnological, geographic, and human use variables as predictors of the presence of Bythotrephes longimanus in Canadian Shield lakes. Can J Fish Aquat Sci 67(3):462-472

Yan ND, Pawson TW (1997) Changes in the crustacean zooplankton community of Harp Lake, Canada following the Bythotrephes cederstroemi invasion. Freshw Biol 37:409-425

Yan ND, Dunlop WI, Pawson TW, MacKay LE (1992) Bythotrephes cederstroemi (Schoedler) in Muskoka lakes: first records of the European invader in inland lakes in Canada. Can J Fish Aquat Sci 49:422-426

Yan ND, Blukacz A, Sprules WG, Kindy PK, Hackett D, Girard RE, Clark BJ (2001) Changes in zooplankton and the phenology of the spiny water flea, Bythotrephes, following it invasion of Harp Lake, Ontario, Canada. Can J Fish Aquat Sci 58:2341-2350

Yan ND, Girard R, Boudreau S (2002) An introduced invertebrate predator (Bythotrephes) reduces zooplankton species richness. Ecol Lett 5:481-485

Young JD, Loew ER, Yan ND (2009) Examination of direct daytime predation by Coregoni artedi on Bythotrephes longimanus in Harp Lake, Ontario, Canada: no evidence for the refuge hypothesis. Can J Fish Aquat Sci 66(3):449-459

Yurista PM (1997) Bythotrephes cederstroemi diapausing egg distribution and abundance in Lake Michigan and the environmental cues for breaking diapause. J Great Lakes Res 23:202-209

Yurista PM (1999) A model for temperature correction of sizespecific respiration in Bythotrephes cederstroemi and Daphnia middendorffiana. J Plankton Res 21(4):721-734

Yurista PM, Vanderploeg HA, Liebig J, Cavaletto JF (2010) Lake Michigan Bythotrephes prey consumption estimates for 1994-2003 using a temperature and size corrected bioenergetic model. J Great Lakes Res 36(sp3):74-82. doi:10.1016/j.jglr.2010.03.007

Zoltak J (2010) Ontario federation of anglers and hunters. 4601 Guthrie Dr., Peterborough, ON K9J 8L5 Canada 